\author{
$14^{\text {th }}$ Symposium on Nutri Indonesia \\ in conjunction with \\ $6^{\text {th }}$ International Nutrition Symposium \\ July 27-28, 2019 | Jakarta, Indonesia
}

\title{
ABSTRACT
}

\section{Association between Exclusively Breastfed Infant and Picky Eating Behavior in Children below Five Years Old: A Cross-Sectional Study}

Ernestive Vivi Sadeli

General Practitioner, RS TNI-AD Tk. IV, Kencana Serang, Banten, Indonesia

Link to DOI:

10.25220/WNJ.V03.i1.0012

Journal Website:

www.worldnutrijournal.org

Background: Picky eating behaviors are prevalent during childhood and often linked to nutritional problems. Environmental factors play a role in taste and eating preferences, such as genetics, learning experiences, and culture including exclusive breast fed for six months. Nutritional problems deserve special attention for its long term consequences such as malnutrition, stunting, infection, social and cognitive impairment. In Indonesia, 50-60\% parents have problems with picky eating behavior with their children. ${ }^{1}$

Objective: To investigate association between exclusively breastfed infant and picky eating behavior.

Methods: A cross-sectional study with purposive sampling was performed in 208 children at age below $5^{\text {th }}$ years old in Serang. To assess picky eating behavior, the writer use Children Eating Behavior Questionnaire especially for food fussiness section (CEBQ-FF). Based on WHO recommendation, breast fed infant is infants that receive only breast milk for 6 months as an optimal way of feeding infants. Statistical analysis using chi square with $p$ value $<0.05$ considered being significant and odds ratio $>1$ considered have causal effect.

Results: Among 208 children, there are 123 children (59\%) that have picky eating behavior and 43 children of them are exclusively breast fed. There is a relationship between exclusively breast fed infant and picky eating behavior $(\mathrm{p}=0.037)$. Exclusively breast fed is protective to picky eating behavior in children below $5^{\text {th }}$ years old $(\mathrm{OR}=0.43$; CI 95\% $=0.51-0.6)$.

\begin{tabular}{|c|c|c|c|c|}
\hline \multirow{2}{*}{$\begin{array}{l}\text { Exclusive breast } \\
\text { fed }\end{array}$} & \multicolumn{2}{|c|}{ Picky eaters } & \multirow[t]{2}{*}{ p value } & \multirow[t]{2}{*}{ OR $(95 \%$ CI $)$} \\
\hline & Yes & No & & \\
\hline Yes & 43 & 47 & 0.037 & $0.43(0.51-0.6)$ \\
\hline No & 80 & 38 & & \\
\hline
\end{tabular}

Conclusion: From this study, there are 59\% children that have picky eating behavior. Exclusively breast fed for six months is protective to picky eating behavior in children below $5^{\text {th }}$ years old, which corresponds well with WHO recommendations.

Corresponding author:

Ernestine Vivi Sadeli

RS Kencana Serang - Jalan Jendral Ahmad Yani No. 21-23, Sumurpecung, Serang, Cimuncang, Kec. Serang, Kota Serang, Banten 42117.

Email address: ernestine.vivi@gmail.com 